\title{
The Effects of Sodium Fluorescein Dyeing of Metastatic Brain Tumors on Surgical Outcomes Under Microsurgical Operation
}

\author{
Metastatik Beyin Tümörlerinin Mikrocerrahi Yönetiminde Sodyum Fluorescein Boyamanın \\ Cerrahi Sonuçlara Etkileri
}

\author{
(D) Tamer TUNÇKALE, (D) Tezcan ÇALIŞKAN \\ Tekirdağ Namık Kemal University Faculty of Medicine, Department of Neurosurgery, Tekirdağ, Turkey
}

\begin{abstract}
Aim: We investigated the reflection of tumor dyeing (staining), an auxiliary technique for the resection of metastases, which are the most prevalent group among brain tumors, via microsurgery.

Materials and Methods: Twenty one patients, who were operated under surgical white light, and 27 patients who were operated via sodium fluorescein (FL) dyeing (staining) due to metastatic brain tumors were evaluated retrospectively. The gross total resection (GTR) rates, surgical time, amount of blood loss, and the duration of hospital stay for both groups were compared. The contribution of FL dyeing (staining) to surgery was evaluated for the group with FL dyeing (staining).

Results: The study comprised of 48 patients in total. The median age of patients was 61.5 years (minimum: 20, maximum: 80), the average age was $59.1 \pm 11.8$ years. There was no difference between the group with FL dyeing and the one without dyeing in terms of gender, age, tumor size, GTR rates and surgical time. Blood loss and duration of hospital stay in the FL used group was significantly less. In the group with FL dyeing (staining) (92.5\%), this method contributed to the surgery by giving yellow highlights.

Conclusion: It has been found out that in the surgery of metastatic brain tumors, FL dyeing decreases the blood loss, shortens the surgical time, and aids in the differentiation of tumor glial tissue.
\end{abstract}

Keywords: Sodium fluorescein, microsurgery, metastatic brain tumors

ÖZ

Amaç: Beyin tümörleri içerisinde en sık görülen grup olan metastazların mikrocerrahi ile çıkartılmasında yardımcı bir teknik olan tümör boyamanın cerrahi sonuçlarımıza yansımasını araştırdık.

Gereç ve Yöntem: Metastatik beyin tümörü nedeni ile mikrocerrahi yöntem ile beyaz ışık altında opere edilen 21 hasta ve sodyum fluorescein (FL) boyama kullanılan 27 hasta retrospektif olarak değerlendirildi. Her iki grubun gross total rezeksiyon (GTR) oranları, cerrahi süreleri, kan kaybı miktarları, hastanede kalış süreleri karşılaştırıldı. FL kullanılan grupta boyamanın cerrahiye yaptığı katkı değerlendirildi.

Bulgular: Çalışmaya toplamda 48 hasta alındı. Hastaların medyan yaşı 61,5 (minimum: 20 maksimum: 80) yıl, ortalama yaşı 59,1¹1,8 yıl idi. FL kullanılmayan ve kullanılan gruplarda cinsiyet, yaş, tümör büyüklüğü, GTR oranları ve cerrahi süre açısından fark yoktu. FL kullanılan grupta kan kaybı miktarları ve hastanede kalış süresi belirgin şekilde azdı. FL kullanılan grupta yirmi beş hastada $(\% 92,5)$ FL sarı röfle vererek cerrahiye katkı sağlamıştır.

Sonuç: Metastatik beyin tümörlerinin cerrahisinde FL boyama kan kaybını ve cerrahi süreleri azaltmakta, tümör glial doku ayrımında cerraha yardımcı olmaktadır.

Anahtar Kelimeler: Sodyum fluorescein, mikrocerrahi, metastatik beyin tümörleri

Address for Correspondence: Tamer TUNÇKALE MD, Tekirdağ Namık Kemal University Faculty of Medicine, Department of Neurosurgery, Tekirdağ, Turkey Phone: +90 5053737103 E-mail: ttunckale@hotmail.com ORCID ID: orcid.org/0000-0002-4534-0864

Received: 07.03.2021 Accepted: 18.04.2021

๑ Copyright 2021 by the Tekirdağ Namık Kemal University Faculty of Medicine / Namık Kemal Medical Journal published by Galenos Publishing House. 


\section{INTRODUCTION}

Cerebral metastases are the most common lesions among all brain tumors and are more common than primary glial masses $^{1}$. Cerebral metastases can be seen in $20-40 \%$ of patients with known cancer, while approximately $70 \%$ of these patients are symptomatic ${ }^{2}$. As a result of the success in the treatment of the primary disease in recent years, prolonged life expectancy, accessibility to imaging methods, and advances in the techniques of these methods have led to an increase in the incidence of brain metastases ${ }^{3}$. While life expectancy is expressed in months in many patients with brain metastases, it is known that surgery, whole-brain radiotherapy and chemotherapy treatment algorithm, respectively, are the treatment modalities that increase total survival the most in the recent period ${ }^{4,5}$. The aim of surgery, which is the first step of the treatment in these patients, is total resection ${ }^{6}$. The higher the amount of resection, the less the possibility of local recurrence? ${ }^{7}$ Recently, many methods such as navigation systems, brain mapping, fluorescein (FL) staining, intraoperative ultrasound and magnetic resonance (MR) have been used to increase the surgical safety and the amount of resection in brain tumors ${ }^{8,9}$. Sodium FL, a FL salt, is a water-soluble organic dye that has been used safely in eye angios for a long time and accumulates in areas where the blood-brain barrier is disrupted ${ }^{10}$. Brain tumors cause contrast enhancement by disrupting the blood-brain barrier where they are located. FL has been used for many years in standard surgical microscopes that give off white light or with the naked eye at high doses of $15-20 \mathrm{mg} / \mathrm{kg}$ in order to distinguish tumor glial tissue in contrast-enhancing areas ${ }^{11}$.

Side effects, up to anaphylaxis, have been avoided by using low doses of 3-4 $\mathrm{mg} / \mathrm{kg}$, thanks to filters that give a yellow highlight to FL at a wavelength of $560 \mathrm{~nm}$, which have recently been installed on surgical microscopes ${ }^{12}$. There are studies showing that the use of $\mathrm{FL}$ in brain metastases increases the amount of resection ${ }^{13,14}$. We will also present the results, surgical differences and our experience in patients with brain metastases in which we used and did not use FL staining with a $560 \mathrm{~nm}$ filter microscope in surgery.

\section{MATERIALS AND METHODS}

In our clinic, 21 patients (group 1) who were operated under white light by two surgeons in 2015-2016 due to metastatic brain tumors and 27 patients (group 2) who were operated between 2017-2019 by performing FL staining were evaluated retrospectively.

Patients with significant contrast enhancement on MR images, aged between 34-75 years, diagnosed with metastatic brain tumor and who underwent surgery were included in the study. Cases that did not have contrast enhancement on
MR images and for whom administering contrast agent was contraindicated were excluded from the study.

All patients were operated under general anesthesia. Group 1 patients were operated under white light with a standard surgical microscope. In group 2 patients, $3 \mathrm{mg} / \mathrm{kg}$ FL was given as a $10 \%$ bolus through the central catheter before the skin incision following the induction of anesthesia. Leica M530 OHX (Wetzlar and Mannheim, Germany) microscope with FL560 fluorescein module was used in the surgery of the patients. The yellow highlights around the tumor tissue under FL560, which could not be clearly differentiated under white light, were excised. Contrast-enhanced control brain MRIs taken at the first month after surgery were evaluated with open source software (Sectra UniView, https://medical.sectra.com/product/ sectra-uniview) and residual tumor volumes were calculated. Patients with no contrast enhancement in postoperative MR images were evaluated as gross total resection (GTR), while those with contrast enhancement were considered as subtotal resection. Length of hospital stay, duration of surgery and amount of blood loss were recorded from patient files. NA-FL's aid to surgery was evaluated by examining the surgery notes and surgery videos.

\section{Statistical Analysis}

Data were analyzed by entering Statistical Package for the Social Sciences (SPSS) 24.0 (SPSS Inc., Chicago, IL, USA) statistical computer program. Chi-square test for categorical variables (Fisher's Exact test if not applicable) was used to compare the groups using NA-FL and those not using it. In comparison of continuous variables, independent sample t-test was used for those with normal distributions and Mann-Whitney $U$ test for those without normal distribution. The cases where the $p$ value was below 0.05 and the type 1 error level was below 5\% were interpreted as statistically significant.

\section{RESULTS}

A total of 48 patients were included in the study. The median age of the patients was 61.5 years (minimum: 20, maximum: 80 ), and the mean age was $59.1 \pm 11.8$ years. In group 1, 21 patients (female $=9$ and male $=12$ ) were operated without using $\mathrm{NA}-\mathrm{FL}$, and in group 2, 27 patients (female=11 and male=16) were operated using NA-FL. There was no difference between the groups in terms of gender $(p=0.883)$. When the mean tumor volumes detected in the contrast-enhanced brain MR images of the patients before the operation were examined, it was seen that it was $13.7 \pm 11.4 \mathrm{~cm}^{3}$ in group 1 and $13.3 \pm 13.3$ $\mathrm{cm}^{3}$ in group 2, and both groups were similar in this respect $(p=0.540)$. Considering the blood loss during surgery, there was an average of 434.3 cc of bleeding in group 1, and this average was 320.4 cc in group 2. This amount of bleeding in group 2 was significantly less than group $1(p=0.001)$. While the duration of surgery was $275.7 \pm 62.8$ minutes in group 1 , 
it was $272.0 \pm 60.7$ minutes in group 2 and both groups were similar in terms of surgery time ( $p=0.837)$. When the control MR images taken after the operation were examined, the GTR rate in group 2 was 92.6\%, while it was $71.4 \%$ in group 1 $(p=0.059)$ (Figure 1). While the mean hospital stay was $9.6 \pm 5.2$ in group 2, it was $13.5 \pm 7.3$ in group 1 and was significantly longer than group $2(p=0.013)$. Demographic data and results of both groups are summarized in Table 1, primary focus types are summarized in Table 2 and Table 3 . In group 2, it did not appear to be beneficial in two patients with $\mathrm{FL}$, malignant melanoma, and cystic AC adenocarcinoma. In 25 patients $(92.5 \%)$, FL contributed to the surgery by giving a light yellow highlight (Figure 2). No complications were observed in any of the patients who used FL.

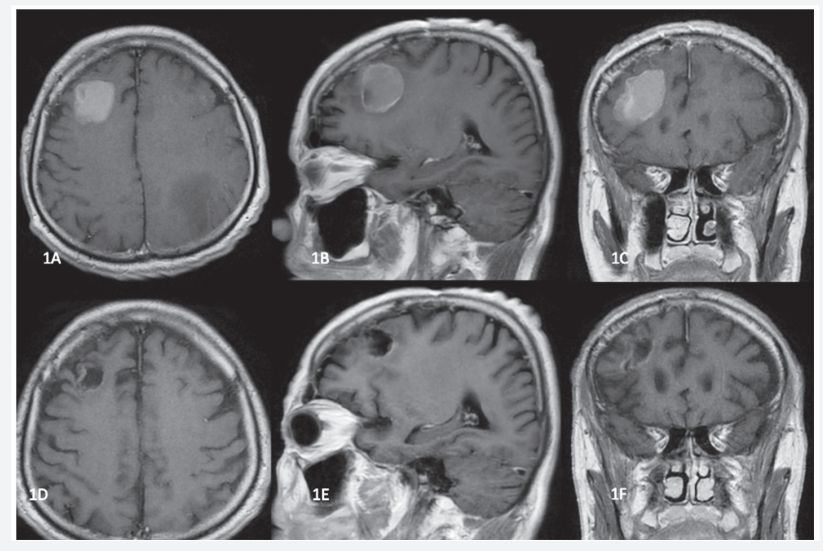

Figure 1. Preoperative and first-month postoperative contrast-enhanced images of the right frontal metastatic mass of a 62-year-old male patient with a diagnosis of $A C$ $\mathrm{Ca}$, for whom fluorescein was used in his surgery; (1A) Preop T1W axial section, (1B) Preop T1W sagittal section, (1C) Preop T1W coronal section, (1D) Postop T1W axial section, (1E) Postop T1W sagittal section, (1F): Postop T1W coronal section

\section{DISCUSSION}

The life expectancy of a patient with a metastatic brain tumor is usually quite short, regardless of which organ the primary tumor originates from. Active physical activity, presence of a solitary metastatic mass, no signs of systemic metastasis, and young age ( $<60-65$ years) are generally associated with a good prognosis ${ }^{15,16}$. In addition to these, total resection and mini-

\begin{tabular}{|c|c|c|}
\hline Cancer type & Incidence & $\begin{array}{l}\text { Percentage } \\
(\%)\end{array}$ \\
\hline AC ca adenocarcinoma & 10 & 47.6 \\
\hline AC ca squamous carcinoma with he & 3 & 14.3 \\
\hline AC ca carcinoma with small he & 1 & 4.8 \\
\hline Ewing sarcoma & 1 & 4.8 \\
\hline Colon ca & 1 & 4.8 \\
\hline Breast ca & 4 & 19.0 \\
\hline Rectum ca & 1 & 4.8 \\
\hline Total & 21 & 100.0 \\
\hline \multicolumn{3}{|l|}{ Ca: Carcinoma, FL: Fluorescein } \\
\hline
\end{tabular}

\begin{tabular}{|l|l|l|}
\hline Table 3. Primary tumor distribution of group 2 & (FL) patients \\
\hline Cancer type & Incidence & $\begin{array}{l}\text { Percentage } \\
(\%)\end{array}$ \\
\hline AC ca adenocarcinoma & 14 & 51.9 \\
\hline AC ca squamous carcinoma with hc & 1 & 3.7 \\
\hline AC ca carcinoma with small hc & 4 & 14.8 \\
\hline Clear cell carcinoma & 1 & 3.7 \\
\hline Malignant melanoma & 1 & 3.7 \\
\hline Breast ca & 5 & 18.5 \\
\hline Rectum ca & 1 & 3.7 \\
\hline Total & 27 & 100.0 \\
\hline Ca: Carcinoma, FL: Fluorescein & & \\
\hline
\end{tabular}

Table 1. Demographic characteristics and surgical results of patients with and without sodium fluorescein

\begin{tabular}{|c|c|c|c|c|c|c|}
\hline \multirow{2}{*}{\multicolumn{2}{|c|}{ 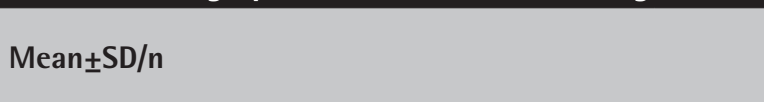 }} & \multicolumn{2}{|c|}{ Group 1 (non-FL) } & \multicolumn{2}{|c|}{ Group 2 (FL) } & \multirow[b]{3}{*}{$0.220^{t}$} \\
\hline & & \multirow{2}{*}{\begin{tabular}{|l|} 
Median \\
$56.8 \pm 14.1$ \\
\end{tabular}} & \multirow{2}{*}{$\begin{array}{l}\text { Mean } \pm \text { SD/n } \\
59.0\end{array}$} & \multirow{2}{*}{$\begin{array}{l}\text { Median } \\
61.0 \pm 9.5\end{array}$} & \multirow{2}{*}{$\begin{array}{l}\text { p value } \\
63.0\end{array}$} & \\
\hline Age & & & & & & \\
\hline \multirow{2}{*}{ Gender } & Female & $9(42.9 \%)$ & & $11(40.7 \%)$ & & \multirow{2}{*}{$0.883^{\times 2}$} \\
\hline & Male & $12(57.1 \%)$ & & $16(59.3)$ & & \\
\hline \multirow{2}{*}{ GTR } & Yes & $15(71.4 \%)$ & & $25(92.6)$ & & \multirow{2}{*}{$0.059^{f}$} \\
\hline & None & $6(28.6 \%)$ & & $2(7.4)$ & & \\
\hline Bleeding amount (cc) & & $434.3 \pm 147.8$ & 440.0 & $320.4 \pm 73.7$ & 320.0 & $0.001^{\mathrm{t}}$ \\
\hline Duration of surgery (min) & & $275.7 \pm 62.8$ & 280.0 & $272.0 \pm 60.7$ & 255.0 & $0.837^{\mathrm{t}}$ \\
\hline Tm volume $\left(\mathrm{cm}^{3}\right)$ & & $13.7 \pm 11.4$ & 12.0 & $13.3 \pm 13.3$ & 9.9 & $0.540^{\mathrm{m}}$ \\
\hline Duration of hospitalization (day) & & $13.5 \pm 7.3$ & 13.0 & $9.6 \pm 5.2$ & 8.0 & $0.013^{\mathrm{m}}$ \\
\hline \multicolumn{7}{|c|}{ SD:Standard deviation, FL: Fluorescein, GTR: Gross total resection, min: Minute. } \\
\hline \multirow{2}{*}{\multicolumn{7}{|c|}{ 't-test, ${ }^{x 2}$ chi-square test, FFisher's Exact test, "Mann-Whitney U test. }} \\
\hline & & & & & & \\
\hline
\end{tabular}




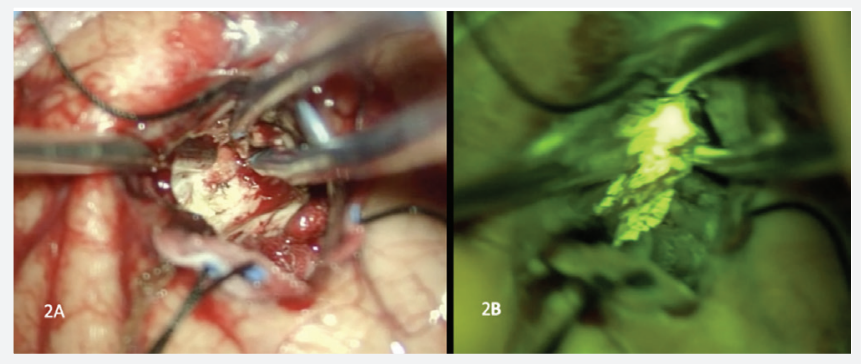

Figure 2. Intraoperative image of the patient whose preoperative and postoperative images are given in Figure 1; (2A) Intra-tumor image following cortical incision under white light, (2B) Tumor tissue appears as bright yellow highlight under FL560 filter

mental testing of the patient, namely memory and cognitive functions. are also associated with good prognosis ${ }^{13,17}$. In brain tumor surgery, the surgeon should ensure that these prognostic factors do not change. The target of the surgery should be total resection, but the patient's motor, memory and cognitive functions should not be affected. For this purpose, in recent years, auxiliary techniques such as intraoperative ultrasound, intraoperative $M R$, navigation, and brain mapping have been used $^{8}$. In recent years, tumor staining techniques using substances such as 5-ALA, FL and indocyanine green have been a light of hope in distinguishing glial tissue from tumors. Highdose $(15-20 \mathrm{mg} / \mathrm{kg}) \mathrm{FL}$ in brain tumor surgery has been used for many years to increase the amount of resection. More secure and clearer images are obtained at doses of 3-4 $\mathrm{mg} / \mathrm{kg}$ thanks to special filters that give a yellow highlight with $\mathrm{FL}$ at $560 \mathrm{~nm}$, which are recently attached to surgical microscopes ${ }^{18,19}$. Thus, GTR rates have increased in both primary glial and metastatic masses with contrast enhancement ${ }^{18,20}$. Schebesch et al. ${ }^{14}$ in their series of 30 patients in which they used low-dose FL with a yellow 560 filter, reported that FL gave bright highlight in 27 patients and was beneficial in surgery, with a GTR rate of 83.3\%. They found that FL was not helpful in two patients with $\mathrm{AC}$ adenocarcinoma and one patient with malignant melanoma.

Again, Hamamcıoğlu et al. ${ }^{20}$ in their series of 23 primary glial tumors and 7 metastatic masses, reported that FL was beneficial in all of their patients, except for one low-grade glial mass. Okuda et al. ${ }^{21}$ reported the GTR rate as $86.1 \%$ and the local recurrence rate as $19.4 \%$ in 36 patients with metastatic brain tumors for whom FL was used. Although there was no statistical significance between the two groups in our series, when we looked at the GTR ratios, it was $71.4 \%$ in white light and 92.6\% in those using FL (Table 1). We think that GTR ratios should be compared in larger series. The increase in GTR with FL in metastatic brain tumors can be explained by the resection of the yellow highlights on the walls by switching to the filter, especially after cleaning the inside of the lodge with debulking. FL was not found to be beneficial in two cases with a cystic $\mathrm{AC}$ adenocarcinoma and a malignant melanoma metastasis.

In retrospect, the patient with $\mathrm{AC}$ adenocarcinoma showed very weak thin-edged contrast enhancement around the cyst in preoperative MR images. FL involvement is proportional to impaired blood-brain barrier and intense contrast enhancement ${ }^{22}$. Especially in cystic masses, there is a thin wall enhancement, FL efficiency should be evaluated in larger series in these patients. FL involvement was not observed in the patient with malignant melanoma metastasis, but the black, gray tumor could easily be separated from the brain tissue. There is no study in the literature regarding the amount of bleeding, surgical durations, and hospital stays in surgeries performed with FL yet. In our series, blood loss in the FL group was significantly less than in the other group $(p=0.001)$ (Table 1). We think that the reason for this is that the surgeon acts more controlled and decisively because he distinguishes between tumor and neural tissue while inside or outside the tumor. Again, in the FL group, by minimizing neural tissue damage, patients were discharged from the hospital more rapidly in the postoperative period ( $p=0.013$ ) (Table 1$)$. The low amount of bleeding in the patients causes the preservation of brain perfusion during surgery. Both the preservation of brain perfusion and the preservation of their motor and cognitive abilities without damaging the glial tissue caused the patients to return to their normal lives more quickly.

\section{Study Limitations}

While it would be appropriate to say that the use of $F L$ is an effective method in the surgery of AC Ca metastases, which are the most common in our series of metastatic brain tumors, more cases should be evaluated for this inference in rare metastatic masses and cystic metastases.

\section{CONCLUSION}

$\mathrm{FL}$, which has recently been used mainly in the surgery of highgrade glial masses, is also extremely useful in the surgery of contrast-enhancing metastatic brain tumors. It increases GTR rates, reduces blood loss and hospital stay, as a guide to the surgeon in separating the tumor glial tissue border.

\section{Ethics}

Ethics Committee Approval: The study were approved by the Tekirdağ Namık Kemal University of Ethics Committee (protokol no: E-39550, date: 28.07.2020.)

Informed Consent: Retrospective study.

Peer-review: Externally peer-reviewed. 


\section{Authorship Contributions}

Surgical and Medical Practices: T.T., T.Ç., Concept: T.T., Design: T.T., Data Collection or Processing: T.T., T.Ç., Analysis or Interpretation: T.T., Literature Search: T.T., T.Ç., Writing: T.T.

Conflict of Interest: No conflict of interest was declared by the authors.

Financial Disclosure: The authors declared that this study received no financial support.

\section{References}

1. Arnold SM, Patchell RA. Diagnosis and management of brain metastases. Hematol Oncol Clin North Am. 2001;15:1085-107.

2. Soffietti R, Rudā R, Mutani R. Management of brain metastases. J Neurol. 2002;249:1357-69.

3. Gavrilovic IT, Posner JB. Brain metastases: epidemiology and pathophysiology. J Neurooncol. 2005;75:5-14.

4. Patchell RA, Tibbs PA, Walsh JW, Dempsey RJ, Maruyama Y, Kryscio RJ, et al. A randomized trial of surgery in the treatment of single metastases to the brain. N Engl J Med. $1990 ; 322: 494-500$.

5. MacGee EE. Surgical treatment of cerebral metastases from lung cancer. The effect on quality and duration of survival. J Neurosurg. 1971;35:41620.

6. Narita $Y$, Shibui S. Strategy of surgery and radiation therapy for brain metastases. Int J Clin Oncol. 2009;14:275-80.

7. Olesrud IC, Schulz MK, Marcovic L, Kristensen BW, Pedersen CB, Kristiansen $C$, et al. Early postoperative MRI after resection of brain metastasescomplete tumour resection associated with prolonged survival. Acta Neurochir (Wien). 2019;161:555-65

8. Bush NA, Chang SM, Berger MS. Current and future strategies for treatment of glioma. Neurosurg Rev. 2017;40:1-14.

9. Weller M, van den Bent M, Tonn JC, Stupp R, Preusser M, Cohen-JonathanMoyal E, et al. European Association for Neuro-Oncology (EANO) guideline on the diagnosis and treatment of adult astrocytic and oligodendroglial gliomas. Lancet Oncol. 2017;18:e315-29.

10. Diaz RJ, Dios RR, Hattab EM, Burrell K, Rakopoulos P, Sabha N, et al. Study of the biodistribution of fluorescein in glioma-infiltrated mouse brain and histopathological correlation of intraoperative findings in high-grade gliomas resected under fluorescein fluorescence guidance. J Neurosurg. 2015; 122:1360-9.
11. Koc K, Anik I, Cabuk B, Ceylan S. Fluorescein sodium-guided surgery in glioblastoma multiforme: a prospective evaluation. $\mathrm{Br} \mathrm{J}$ Neurosurg. 2008;22:99-103.

12. Dilek $\mathrm{O}$, Ihsan $\mathrm{A}$, Tulay $\mathrm{H}$. Anaphylactic reaction after fluorescein sodium administration during intracranial surgery. J Clin Neurosci. 2011;18:430-1.

13. Gempt J, Meyer B. Does fluorescein sodium-guided resection of cerebral metastases increase rates of total resections? Acta Neurochir (Wien). 2015;157:897.

14. Schebesch $\mathrm{KM}$, Hoehne J, Hohenberger $\mathrm{C}$, Proescholdt $\mathrm{M}$, Riemenschneider MJ, Wendl C, et al. Fluorescein sodium-guided resection of cerebral metastases-experience with the first 30 patients. Acta Neurochir (Wien). 2015;157:899-904.

15. Gaspar L, Scott C, Rotman M, Asbell S, Phillips T, Wasserman $T$, et al. Recursive partitioning analysis (RPA) of prognostic factors in three Radiation Therapy Oncology Group (RTOG) brain metastases trials. Int J Radiat Oncol Biol Phys. 1997;37:745-51.

16. Lagerwaard FJ, Levendag PC, Nowak PJ, Eijkenboom WM, Hanssens PE, Schmitz PI. Identification of prognostic factors in patients with brain metastases: a review of 1292 patients. Int J Radiat Oncol Biol Phys. 1999:43:795-803.

17. Murray KJ, Scott C, Zachariah B, Michalski JM, Demas W, Vora NL, et al. Importance of the mini-mental status examination in the treatment of patients with brain metastases: a report from the Radiation Therapy Oncology Group protocol 91-04. Int J Radiat Oncol Biol Phys. 2000;48:5964.

18. Acerbi F, Broggi M, Eoli M, Anghileri E, Cuppini L, Pollo B, et al. Fluoresceinguided surgery for grade IV gliomas with a dedicated filter on the surgical microscope: preliminary results in 12 cases. Acta Neurochir (Wien). 2013;155:1277-86.

19. Marbacher S, Klinger E, Schwyzer L, Fischer I, Nevzati E, Diepers M, et al. Use of fluorescence to guide resection or biopsy of primary brain tumors and brain metastases. Neurosurg Focus. 2014;36:E10.

20. Hamamcıoğlu MK, Akçakaya MO, Göker B, Kasımcan MÖ, Kırış T. The use of the YELLOW $560 \mathrm{~nm}$ surgical microscope filter for sodium fluoresceinguided resection of brain tumors: Our preliminary results in a series of 28 patients. Clin Neurol Neurosurg. 2016;143:39-45.

21. Okuda T, Kataoka K, Yabuuchi T, Yugami H, Kato A. Fluorescence-guided surgery of metastatic brain tumors using fluorescein sodium. J Clin Neurosci. 2010;17:118-21.

22. Diaz RJ, Dios RR, Hattab EM, Burrell K, Rakopoulos P, Sabha N, et al. Study of the biodistribution of fluorescein in glioma-infiltrated mouse brain and histopathological correlation of intraoperative findings in high-grade gliomas resected under fluorescein fluorescence guidance. J Neurosurg. 2015;122:1360-9. 